Journal of Social and Development Sciences

Vol. 3, No. 6, pp. 203-213, June 2012 (ISSN 2221-1152)

\title{
Bangladesh: An Umpired Democracy
}

\author{
*Abul Kalam Azad 1 , Charles Crothers ${ }^{2}$ \\ ${ }^{1}$ Independent Researcher, Auckland, New Zealand \\ ${ }^{2}$ Auckland University of Technology, New Zealand \\ *kazad9@gmail.com
}

\begin{abstract}
This paper reveals that there has been a continuous political confrontation between two archrival political forces in Bangladesh since independence in 1971. In the course of the confrontation, the country has seemingly been divided into two forces: BAL forces and anti-BAL forces. The democratic development in this country since 1991 is a by-product of this confrontation. In 1991, because of the continued mistrust between the two confronting forces, a unique system of interim government (non-party caretaker government) was produced that kept working as a catalyst of power transfer in a democratic way from one government to another till 2008 election from 1991.
\end{abstract}

Key words: Bangladesh; umpired democracy; Awami League; BNP

\section{Introduction}

Two most attractive attributes of democracy are that it works or attempted to work in favour of at least the majority of a country (Vanhanen, 2003) and allows everybody to become a part of the "majority" through open competition. In democratic competion, parties and leaders theoretically are like commodities in a free market economy, where the quality of the commodities and market forces determine prices. Therefore, Azad (2004) terms democracy as self-operated system as it just needs a free but disciplined society to run. Despite these wooing features, democracy has never been free of criticisms. One of these criticisms is that democracy leaves minority somewhat open to victimisation by majority. Besides, well-off individuals and parties have more opportunities to get elected than the poor ones because money is generally powerful enough to earn party nominations and popular votes as well. Nontheless, democracy from the ancient Greek city states (Wollheim, 1958) through the French Revolution (Wejnert, 2005) and the American Declaration of Independence in eithteen century proliferated across the world. Although most of the early democracies could not survive, a steady increase in the number of democratic transitions, specially over the last three decades (Doyle, 1983; Fukuyama, 1992; Grassi, 2002; Gurr, Jagger, \& Moore, as cited in Wejnert, 2005), posted general acceptance and importance of democracy against autocracy. Bangladesh, predominantly a Muslim country with democratic constitution, was a part of Indian state of Bengal until Pakistan was born and included it by dividing India in 1947. It won independence from Pakistan in 1971. Just after less than four years of independence, military took over the country's state power in August 1975, since when direct and indirect military rules had prolonged for the next 15 years. A democratic transition took place in this country in 1991 following the fall of last military dictator General (Rtd.) Hussein Muhammad Ershad in the face of a massive political upheaval at the end of 1990. Since 1991, governments have mostly changed through generally accepted elections. Generally, two leading parties, Bangladesh Awami League (BAL) and Bangladesh Nationalist Party (BNP), have been ruling the country alternately. However, these two parties have been involved in politics of confrontation that leads to dysfunctional or ineffective parliament (Moniruzzaman, 2009), and malfunctioning of democracy (Majumder, n.d.). However, at the same time, major democracy measures (e.g. Freedom House, n.d; Polity, n.d; CSCW, n.d.) have presented Bangladesh as a democratic country in general since 1991. Against this backdrop, some questions are generated: What has been the rootcause of political confrontation in Bangladesh? What factor/s actually drove democratisation in this country and what trend of democratisation the country has been witnessing? To answer these questions, this paper, in fact, attempts to theorise about Bangladesh democracy.

\section{Literature Review}

A large part of democratisation literature (e.g. Schumpeter, 1947; Huntington, 1968; Lipset, 1959; O’Donnell, 1973; Przeworski and Limongi, 1997; Moore 1966; Lerner, 1958; Rostow, 1960; Apter 1965; Rowen, 1995 : 
52; Boix and Stokes, 2003; Geddes 1999; Inglehart and Welzel, 2005) shows that modernisation or economic development is a major factor of democratisation. Therefore, democratisation literature could be divided into two broadly based sections: economic factors and other factors. Other factors focused in the literature are: social, cultural or multivariate (Huntington, 1991), impact of economic crisis on authoritarian regime (Haggard and Kaufmann, 1995), economic liberalisation (Cui, 1997), global flow of democratisation and geographic proximity (O'Loughlin et al,.1998; Kopstein \& Reilly, 2000), role of America (Cox, Ikenberry \& Inoguchi, 2000); EU role (Rupnik, 2000), pro-democracy political institutions (Prezworski et al, 2000; Rose and Shin, 2001); NATO expansion (Barany, 2004); distribution of power and resources in society (Vanhanen, 2004); honest and competent public bureaucracies (Harris, 2004); Foreign aid (Gazibo, 2005); IMF's influence (Nelson \& Wallace, 2005; Mansfield \& Pevehouse, 2006). Negative factors of democratisation included development of political personality cults (Venter, 2003); and competitive authoritarian regimes (e.g. hybrid regime in Singapore) (Brownlee, 2009). Bangladesh political literature has so far focused primarily on political instability and secondarily the 1991 democratic transition as a short-term event rather than on the trend of democratisation. There has been few theoretically grounded works on determinants and trend of the country's democratisation; most writings could be termed as historical descriptions (Khan and Husain, 1996; Ali, 2006; Jahan, 2003; Jahan, 2004; Rashiduzzaman, 2001; Ahmed, 2003; Ahmed, 2001; Kochanek, 2000). In the view Maniruzzaman (1992), the autocratic government fell at the end of 1990 because President General (Rtd.) Hussein Mohammad Ershad failed to maintain good relationships with the military, intellectuals, students, and major political parties. Actually, the fall of the then autocratic regime is mostly attributed to a student-led mass upsurge, withdrawal of military support from President Ershad and the Western donor community's threat to reduce their aid levels on the grounds of corruption (Kochanek, 2000). Moreover, at crucial moments in 1987, 1990 and 1996 civil society advocacies played important roles in so that politicians became united in opposition to the government and then successfully reformed the country's political institutions (Wilkinson, 2000). Lee (2002) also identifies political protests as a primary cause of democratisation and found no relationships between economic development and democratisation in Bangladesh. It is very evident that instability is a major political phenomenon in Bangladesh, which impedes good governance and democratisation, and that the root of this phenomenon is confrontation between two main political forces (Kochanek, 2000). In an investigation into this political instability, Hossain (2000) argues that confrontational politics of two leading political parties, the BAL and the BNP, demonstrates such a political culture where both the parties seek to own state power and do not tolerate each other at all. Ahmed (2003) observes that the system of a non-party caretaker government; external factors such as international election observers and donors; and democratic motivation have played key roles in democratisation in Bangladesh. However, due to a dominant tendency of the two leaders, BAL chief Sheikh Hasina and BNP chief Khaleda Zia, democracy in the country could not have reached the desired level.

\section{Methodology}

The research question of this study is: what factor/s drove democratisation in Bangladesh. Our hypothesis is: Democracy in Bangladesh is a by-product of political confrontation between two archrival political forces. To investigate this question/ hypothesis, our approach is mixed-statistical and political historical that cover the period starting from the country's independence year 1971 to the recent past.

\section{Analysis/ Investigation}

Since economic development as a factor of democratisation is at the forefront of the literature review, we at first check for impact of economic development on democracy in Bangladesh for the period of 1972-2010 using a scatter plot. In the scatter plot, we used GDP per capita data as indicator of economic development, and the Freedom House Political Rights and Civil Liberty data as the indicator of democracy. In the scatter plot test, economic development (GDP per capita) is found to have a weak effect on democratisation (Figure 1) implying that there were some factors other than economic development, which have had a strong impact on democratisation in Bangladesh. 
Figure 1: The weak positive effect of economic development (GDP per capita in US\$) on democracy in Bangladesh, 1972-2010

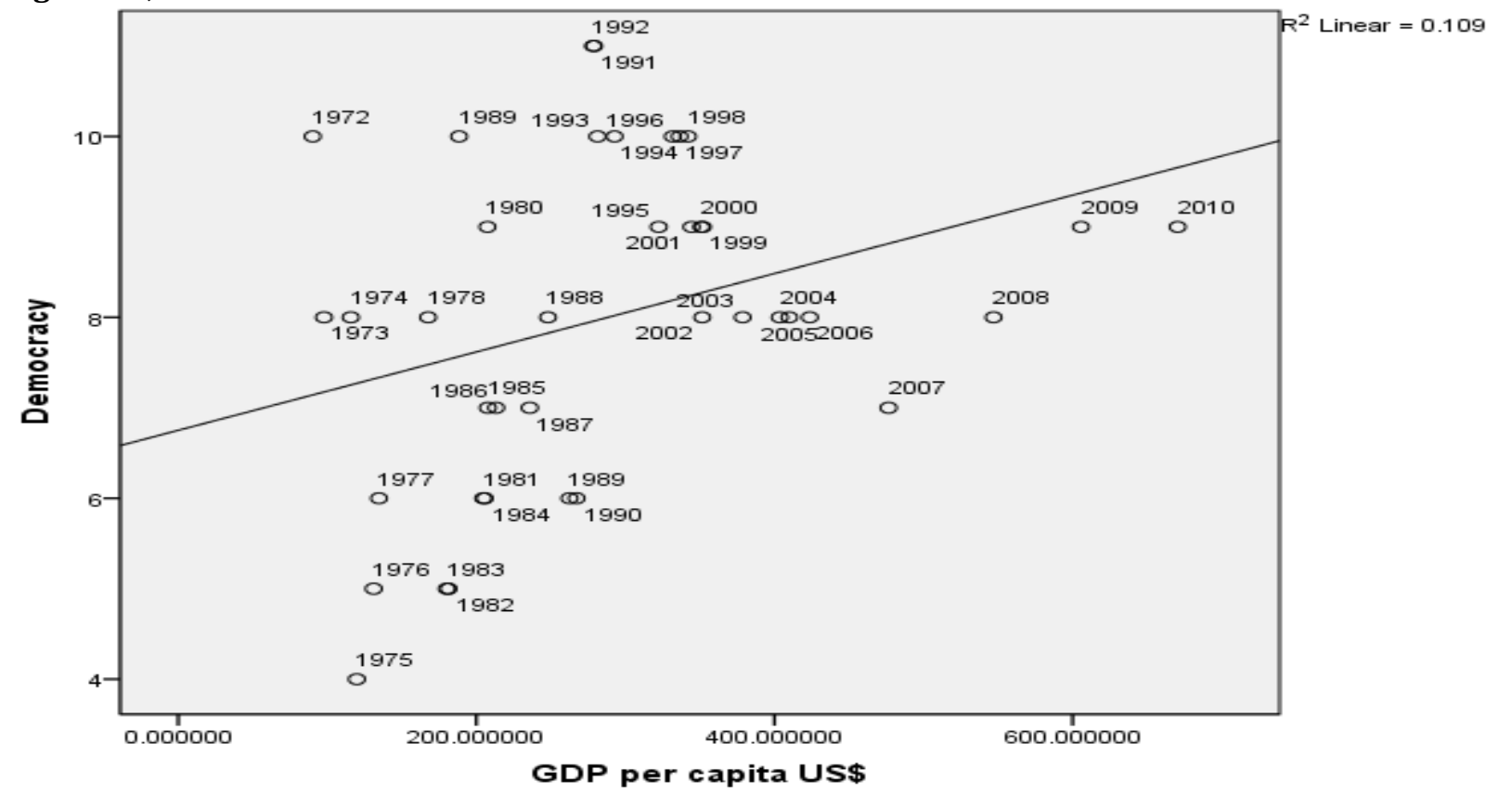

Noting the weak influence of economic development, we opt for political historical investigation. We carry out historical investigation with a clue from Chowdhury (2006) who found a division in voters in Bangladesh. In his view, generally voters were in part either pro-BAL or anti-BAL. This view led to the development of our concept of a national political divide as applied in this study.

Quantitative data: GDP per capita data used in this study are GDP of Bangladesh in current prices in US dollars divided by the population of the county ("UN Stat Conversions and Formulas", n.d.). The GDP data are for 39 years from 1972 to 2010 and all of these data are secondary. These data were collected from UN Statistics Division (UN Stat, n.d.). Democracy data are also secondary and for 1972-2010 period ${ }^{1}$. Each year's scores of Freedom House Political Rights and Civil Liberty (Freedom House, n.d.) data about Bangladesh were aggregated to produce a democracy score, which ranged from 14-2 points. Then, because the lower figures represent bigger values in the original numerical Freedom House data, the figures were rearranged (Table 1) so that the larger figures represented larger values to help with the interpretation. Thus, on the 2-14 point scale, "2" means least democracy while "14" means most democracy.

Table 1: Transformation of Freedom House Political Rights (PR) and Civil Liberties (CL) ratings (7-1) for Bangladesh into 2-14 Bangladesh democracy index, 1972-2010

\begin{tabular}{lllll}
\hline Year & PR & CL & Democracy (14-2) & Democracy (2-14) \\
\hline 1972 & 2 & 4 & 6 & 10 \\
1973 & 4 & 4 & 8 & 8 \\
1974 & 4 & 4 & 8 & 8 \\
1975 & 7 & 5 & 12 & 4 \\
1976 & 7 & 4 & 11 & 5 \\
1977 & 6 & 4 & 10 & 6 \\
1978 & 4 & 4 & 8 & 8 \\
\hline
\end{tabular}

${ }^{1}$ Since Bangladesh fought a bloody war of independence from March to December 1971, we have ignored the collection of the country's economic and democracy for the year. 


\begin{tabular}{|c|c|c|c|c|}
\hline 1989 & 3 & 3 & 6 & \\
\hline 1980 & 3 & 4 & 7 & 9 \\
\hline 1981 & 5 & 5 & 10 & 6 \\
\hline 1982 & 6 & 5 & 11 & 5 \\
\hline 1983 & 6 & 5 & 11 & 5 \\
\hline 1984 & 5 & 5 & 10 & 6 \\
\hline 1985 & 4 & 5 & 9 & 7 \\
\hline 1986 & 4 & 5 & 9 & 7 \\
\hline 1987 & 4 & 5 & 9 & 7 \\
\hline 1988 & 4 & 4 & 8 & 8 \\
\hline 1989 & 5 & 5 & 10 & 6 \\
\hline 1990 & 5 & 5 & 10 & 6 \\
\hline 1991 & 2 & 3 & 5 & 1 \\
\hline 1992 & 2 & 3 & 5 & 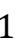 \\
\hline 1993 & 2 & 4 & 6 & \\
\hline 1994 & 2 & 4 & 6 & \\
\hline 1995 & 3 & 4 & 7 & 9 \\
\hline 1996 & 2 & 4 & 6 & \\
\hline 1997 & 2 & 4 & 6 & \\
\hline 1998 & 2 & 4 & 6 & \\
\hline 1999 & 3 & 4 & 7 & 9 \\
\hline 2000 & 3 & 4 & 7 & 9 \\
\hline 2001 & 3 & 4 & 7 & 9 \\
\hline 2002 & 4 & 4 & 8 & 8 \\
\hline 2003 & 4 & 4 & 8 & 8 \\
\hline 2004 & 4 & 4 & 8 & 8 \\
\hline 2005 & 4 & 4 & 8 & 8 \\
\hline 2006 & 4 & 4 & 8 & 8 \\
\hline 2007 & 5 & 4 & 9 & 7 \\
\hline 2008 & 4 & 4 & 8 & 8 \\
\hline 2009 & 3 & 4 & 7 & 9 \\
\hline 2010 & 3 & 4 & 7 & 9 \\
\hline
\end{tabular}

Source: These researchers construct 2-14 points Bangladesh democracy index, 1072-2010 on The basis of Freedom House Political Rights and Civil Liberties scales for Bangladesh

Qualitative data: Qualitative data used for historical investigation in this study are secondary as well and cover the same period of 39 years. These data sources include books, journal articles, magazine and newspaper articles and news, website documents, etc. We organise our study by dividing it into some sections under the headings: Introduction, Literature, Methodology, The democracy: Bangladesh style, Confrontational politics: Tools for fighting each other, and the National political divide, Discussion; and we then conclude.

The democracy: Bangladesh style: It is observed that the two-archrival political forces - one is led by the BAL and the other by BNP -- reached a unique consensus in 1990 to set up a non-party caretaker government $(C G)^{2}$. In 1991, the country's first widely acceptable free and fair election was held under the CG and the country attained its highest degree of democracy (Freedom, n.d.). Under the supervision of this type of interim government, the four parliamentary elections held in the years 1991, 1996, 2001 and 2008 were by

\footnotetext{
${ }^{2}$ The CG was at first constituted for holding the 1991 general elections only. Then, in 1996, the BNP-led government had to make permanent constitutional provision for this sort of interim government as a BAL-led alliance waged a political upheaval demanding it. In 2011, the system was abolished and, accordingly, the next general election is supposed to be held under party government.
} 
and large free, fair and generally accepted though losing major parties criticised the election results every time. Except two years of state of emergency during the rule of an army-backed government in 2007 and 2008, the general trend has not been undemocratic since the 1991 transition as the system of CG was still working somehow for generally acceptable national elections and having a positive influence on democracy. In fact, what democracy virtually has meant in Bangladesh is only formation of government through parliamentary election under a CG. After forming government, the parliament becomes dysfunctional or ineffective because of the long drawn absence of main opposition party; the Opposition takes to the street with destructive behaviour and demands resignation of the elected government; then the ruling party allegedly uses government mechanisms to repress the Opposition, etc. These have been the most common political phenomena ${ }^{3}$ since the so-called democratic transition took place in 1991. Under the circumstances, we would like to term the system of CG as the result of a unique agreement of disagreements between the two conflicting political forces as this system worked as an umpire between the two forces during general elections.

Confrontational politics: Tools for fighting each other: Apart from the unique consensus in 1991, the confronting political forces have used two tools to fight each other: direct undemocratic tools mostly used during the period until the democratic transition took place in 1991; and indirect undemocratic tools have mostly been in use since democratic transition took place. Those tools have been used in order to achieve and remain in power or to block opponent forces from achieving or remaining in power; or to unseat the sitting opponent government.

Direct undemocratic tools: Direct undemocratic tools generally appeared tyrannical and went directly against democracy. The main such undemocratic tools used for political gains were the (1) cancellation of voting rights of some people who collaborated with Pakistani forces during the war of independence in 1971; (2) banning religion-based political parties in 1972; (3) introduction of one-party system in 1975; and (4) all the military coups.

Indirect undemocratic tools: Indirect undemocratic tools have been generally based on political cunning and disguised as democratic. The main such indirect undemocratic tools used for political gains are: 1) financial corruption; 2) abuse of democratic rights; and 3) political corruption. Each of these mechanisms is explained below.

Financial corruption: The conflicting political forces have considered money as one of the key factors in winning elections. Because of this, they gave priority to nominating candidates with money in elections. "The political parties nominate hoodlums, businessmen and unscrupulous industrialists as candidates for winning parliamentary and other elections" (Akram \& Das, 2006). Political parties very often have broken the period and gone over the set limit for spending money in electioneering (Akram \& Das, 2007). Generating money by using government positions in Bangladesh seems to be quite easy as it was rated world's most corrupt country for five consecutive years until 2005 (Transparency International, n. d.). Thus, we are convinced that financial corruption has been a double-edge sword: Political parties spend big amounts of money in electioneering to influence election results and, when in power, try to earn more than they spend using their positions.

Abuse of party rights: Political parties have taken advantages of some of their democratic rights by abusing them. These rights are general strikes (locally called hartal), blockades, public meetings and rallies, and boycotts of parliament. Both the rival political forces, while in opposition, use these democratic rights as an instrument in a bid to drag down an elected government instead of waiting for next election (Rahman, 1993 as cited in Rahman, 2001). They enforce general strikes and blockades in order to press the government to meet their demands. During these protest actions, all sorts of economic activities, modes of transport, and government and private offices suffer a lot. The country was shut down for more than 300 days in the 1990s during the two political regimes (Hossain, 2004). General strikes were costing Bangladesh around $\$ 80$ million per day and became the symbol of Bangladesh's economic and social paralysis (Immigration and Refugee Board of Canada, 1996).

${ }^{3}$ For explanation, see Hossain, 2000; Rahman, 2001; UNDP, 2005; Moniruzzaman, 2009; and Osman, 2010. 
Political corruption: Political corruption can be regarded as more detrimental to a society than any other forms of corruption as it can illegally help transfer political power to an unaccountable person, group or party. However, this study has found no instances of punishment to any persons or organisations involved in political corruption in Bangladesh, although occasionally some people receive some sort of punishment or at least face trial for financial corruption. Such political corruptions found in the history of Bangladesh are: 1) the hastily passed $4^{\text {th }}$ amendment to the constitution; 2) legalising military coups; 3) government recruitments and postings of partisan people to do election-related jobs which would then favour one of the two confronting political forces; 4) preparation of fake voter rolls; 5) politicisation of CG; and 6) alleged partisan move to cancel the system of CG. Each of these actions violated the fundamental democratic principle that the people are the owners of a country and they have to be free to choose their representatives and make decisions on necessary issues in a free and fair manner to run the state affairs. The BAL, with more than twothirds majority, moved the $4^{\text {th }}$ Amendment to the Constitution bill on 25 January 1975 in Parliament and just in 70 minutes time it was passed by voice votes the same day (Huq, 1994). This amendment, on one hand, transformed the country's multiparty democracy to a one party system and, on the other hand, altered a parliamentary form of government to a presidential one. At least 12 military coups ${ }^{4}$ occurred during the period under study, which completely went against basic democratic rules. Among those only three (15 August 1975, 7 November 1975 and 24 March 1982) are considered successful as their leaders survived and ruled the country for a considerable period of time. In all cases of unsuccessful military coups, the coup leaders and participants faced trial in court martial and many of them received capital punishment. In contrast, none of the three successful coup leaders have so far been tried for toppling a government or illegally taking control of the government. Rather, they had the unsuccessful coup leaders tried and their own coups and rules made legal through constitutional amendment.

General Ziaur Rahman, who emerged as the supreme leader after the 7 November 1975 coup, got his own party and political alliance established and elected to the Parliament that legalised all his and the previous coup leaders' actions including coups. The 1982 coup leader General Ershad followed General Zia's way of legalising his role as coup leader and ruler of the country. Then, after coming to power in 1991, the BNP, from which General Ershad took power by force, arranged the trial of Ershad for a number of solely financial corruption cases. In turn, when the BAL came to power in 1996, it removed the legal barriers to bringing to trial those responsible for the killing of founder of the nation and former BAL chief Sheikh Mujibur Rahman and his family members. It also got some financial corruption cases filed against the Prime Minister of the BNP government, Khaleda Zia. Other than these killing and financial corruption cases, no actions have been taken by any governments during the period under study to try any of the successful military coup leaders and rulers for overthrowing a government or illegally running the state affairs. However, in two separate cases filed by individuals, the country's Supreme Court declared the rule of Generals Zia and Ershad illegal ("Ershad's Takeover", 2010) but there have not been any signs yet to try them for unseating a government or for illegally ruling the country. There were also some facts that reveal conscious efforts by both the political forces to manipulate future election results. The four-party alliance government led by BNP, during their 2001-2006 tenure, appointed Justice Aziz as Chief Election Commissioner (CEC). Despite opposition from the BAL forces and a court ruling that the Election Commission's job was to update the existing voter roll, not to prepare a fresh one, the Election Commission during Aziz's tenure prepared a new voter list. Compared to the previous one, the number of voters on the new voter list increased 21.77 percent (Akram \& Das, 2006). However, the Supreme Court in March 2007 cancelled that voter roll ("HC declares void electoral roll", 2007). In December 2007, the High Court declared "illegal" the appointment of Justice MA Aziz as the chief election commissioner ("Aziz's appointment as CEC", 2007). During the tenure of CEC Aziz, in 2005, the Election Commission recruited 300 field-level election officers who were allegedly selected on partisan basis (Akram \& Das, 2006). After the departure of Aziz as CEC, and the BNP-led alliance government, all the election officers had to take a merit test but the people involved in such recruitment process have not yet been tried.

The two political forces also have tussled over the composition of the caretaker government. A parliamentary election was supposed to be held in 2006 with the then last retired Chief Justice Hasan heading the CG. However the BAL forces alleged that the BNP-led government had increased the retirement age for judges from 65 to 67 in order to make sure Justice Hasan was the last retired Chief Justice and so he would be the

\footnotetext{
${ }^{4}$ For further details, see Maniruzzaman, 1992.
} 
first person to have the opportunity to head the CG. In the face of violent protest by the BAL alleging that Justice Hasan was previously a BNP activist, Justice Hasan refused to head the CG. Then President Iajuddin Ahmed, who was elected as a BNP nominee, without trying other options specified in the constitution (South Sea Republic, n.d.), went straight away to the last option and made himself the head (Chief Advisor) of the CG. Then, amid strong Opposition protest led by the BAL, a so-called army-backed CG took over from the Iajuddin-led CG, going beyond the constitutional provision ("Iajuddin quits as chief adviser", 2007) So far, any of these political corruptions have not been tried. Most recently, the country's highest court cancelled the system of CG as it was not run by the elected representatives of the people and, thereby, the system went directly against the democratic spirit of the constitution. However, the court allowed the system for the next two general elections ("SC sets aside caretaker system", 2011). Following the court verdict, the ruling BAL did not give way to the CG system for another two general elections and repealed the CG provision in the Constitution using their two-thirds majority in Parliament. BNP chief and the Leader of the Opposition in Parliament, Khaleda Zia, who is also a former Prime Minister has alleged that the ruling party cancelled the system of CG in a bid to win and cling to power by rigging next election scheduled to be held in early 2014 ("Doors shut", 2011).

National political divide: In the discussion above, it is found that there has been a sharp national political divide in Bangladesh - one side led by the BAL forces and other side by anti-BAL forces. In addition, this divide has been the principal determinant of Bangladesh politics. Since the country's liberation war, the BAL alone has generally been leading the BAL forces while the anti-BAL forces have been led by different parties, e.g. BNP and Jatiya Party (JP) ${ }^{5}$ or military rulers, e.g. General Ziaur Rahman and General Ershad at different points of time. According to our theory of national political divide, we observe that in the whole history of this country, two political forces -- the BAL forces and anti-BAL forces -- have been fighting or competing against each other in major political events, such as the war of independence in 1971, military coups in 1975, and elections. During the war of independence, the conflicting BAL forces and anti-BAL forces have emerged as pro- and anti-liberation forces respectively. The BAL forces led the liberation war while pro-Pakistani Islamic parties e.g. Jamaat-e-Islami (JI) and Muslim League (ML), led the anti-BAL forces and collaborated with Pakistani forces in a bid to block independence of Bangladesh. Through the August 1975 military coup, the BAL forces, i.e. the government headed by founder of the nation Sheikh Mujibur Rahman, were ousted and anti-BAL forces led by a former BAL leader and unelected president, Khondker Mushtaque Ahmed, and some military officers (e.g. colonels Faruque and Rashid, and later General Ziaur Rahman) came to power. After the 1991 democratic transition, an informal alliance of the BNP with JI played the key role in bringing the antiBAL forces to power in 1996 elections. In the 1996 July elections, enmity between these two main anti-BAL parties resulted in a win by the BAL forces. Again, the anti-BAL forces came to power when they were united under an alliance in 2001 elections. So far, only the 2008 election results ${ }^{6}$ have seemed to be non-compliant to our theory of national political divide as the anti-BAL forces with their usual alliance failed to block the victory of the BAL-led alliance. However, this election was held under an army-backed CG and there was a non-established doubt in the political arena that whether the army-backed administration had somehow favoured the BAL in the election.

These two political forces have apparently been leading two different political-psychological blocs. We observe that generally the BAL has an appearance of secularism, and a belief in language and culturally based Bengali nationalism. The BAL believes that Mujib was the most commendable national political hero as he was the founder of the Bangladesh nation. It considered India as a priority friend in the region, and, at the same time, this party does not seem to be ready to accept Pakistan as friend. On the other hand, the anti-BAL parties are commonly opposed to secularism, Bengali nationalism, Sheikh Mujib as top national leader, and India as a friend. They support Islamic values and prioritise Pakistan as friend. They also have inherited

\footnotetext{
${ }^{5}$ Theoretically, we consider that the Ershad-led Jatiya Party has been a component of anti-BAL forces as this party has had the same religious political views as other anti-BAL parties e.g. BNP has had. However, practically, the JP has mostly been aligned with the BAL, as the JP founder General Ershad ousted the BNP government in a coup in 1982 and ruled the country till 1990.

${ }^{6}$ See Poll results 2008, n.d.
} 
Pakistani political culture and heritage that included politics in the name of religion. During the rule of BNP founder General Zia, religious politics was reintroduced which the BAL banned soon after independence of the country (Huq, 1994). We argue that these have been the main features of Bangladeshi nationalism as against Bengali nationalism ${ }^{7}$. We have identified a number of generally conflicting characteristics of the BAL and anti-BAL forces that are shown in the Table 2. The BAL force characteristics have been observed mainly in the BAL However, some smaller parties, e.g. Communist party of Bangladesh, National Awami Party (Mozaffar), Workers Party (Menon), Jatyia Samajtantrik Dal (Inu), Ganatantri Party, etc, have had more or less of these characteristics. Since these parties have not had significant influence on the country's politics and were seen aligned generally with the BAL, we would like to identify them as BAL force components. On the other hand, the BNP, JI, etc, and different individual military rulers more or less have boasted anti-BAL characteristics that put them under the category of anti-BAL forces.

Table 2: Conflicting characteristics of BAL forces and anti-BAL forces

\begin{tabular}{ll}
\hline BAL forces & Anti-BAL forces \\
\hline Secular & Non-secular \\
Pro-Liberation & Anti-Liberation or confusing \\
Pro-Mujib & Anti-Mujib \\
Pro-India & Anti-India \\
Anti-Pakistan & Pro-Pakistan \\
Bengali nationalism & Bangladeshi nationalism \\
\hline
\end{tabular}

Sources of information: Huq, 1994; Hossain, 2001.

Discussion: In the Introduction section, we identified some questions and hinted at a theory about democracy in Bangladesh. Accordingly, our findings presented above reveal that the country has been political-psychologically divided into two forces: one has inherited Pakistani political culture and heritage while the other one is with pride of 1971 independence war against Pakistan and anti-Pakistani politicalcultural orientation. These two forces are rigid on their own orientation and have been in confrontation since the country's independence. In this study, democracy is found to be the by-product of their longstanding confrontation. Because of their arc-rivalry and distrust, they have not wanted any general elections held under each other's administration and this was why they reached a consensus in 1990 on setting up the CG to administer future general elections in acceptable manners. This consensus generated united political movement in 1990 that caused downfall of General Ershad's regime. Afterwards, since 1991, the general elections have been held under the CG; and mainly because of generally accepted elections, democracy have been able to survive continued confrontational situation. It has been observed that any scientific innovation or discovery generally develop against the backdrop of a particular problem in a particular area. Development of political theories and institutions are not also different from this idea. Established old democracies e.g. the United States (USA), the United Kingdom (UK) and India have developed under their own socio-economic-political circumstances. As a result, for example, British, Indian and Singaporean parliamentary systems are not exactly identical. Supremacy of British Parliament is the result of continuous fight between Parliament and the Monarch, which has led to weak judiciary. On the other hand, Indian parliamentarianism is determined by the supremacy of the country's Constitution, and court is the absolute interpreter of the Constitution as India is a multiethnic plural society that has a sort of federal system. Besides, it is hard to term Singapore a democracy as the People's Action Party has been ruling the country for more than 4 decades although the country has inherited British parliamentary institutions since the colonial era. In Bangladesh, democratisation had to start under confrontational circumstances. This confronting situation essentially requires the system of CG for holding acceptable elections. This kind of election is held under outgoing party government in the traditional democracies. Therefore, Bangladesh democracy is not comparable with the traditional democracies, and traditional theory of democracy is not able to explain

7 There is a view in the political arena of Bangladesh that Bangladeshi nationalism has emerged to theoretically include all the Bangladeshi non-Bengali ethnic groups and exclude Indian Bengali population. We observe that these two are at best weak elements of Bangladeshi nationalism as none of these has ever become a mainstream political issue. 
Bangladesh democracy. We would like to call it-umpired democracy, because (1) general election is the only meaningful element of this democracy, and (2) the election is acceptable only when it is umpired by CG.

\section{Conclusion}

What we call 'umpired democracy' in the Discussion section has actually been a 'better' way of power transfer from one government to another in an 'undemocratic environment'. It is 'better' because the general elections held under caretaker governments have been generally free, fair and acceptable in comparison with the ones held under party governments before. It is an 'undemocratic environment' because, firstly, the caretaker government was neither run by people's representatives, nor accountable to the people, and, secondly, the two confronting political forces have been out to fight each other in such ways where rules and norms of democracy have very often been violated indiscriminately. However, no single piece of research can hope to give a thorough answer to any question worth asking, and this study has some shortcomings that should be addressed with more research. For example, absence of military coup is a major reason for democracy to keep going but this study has not investigated why military has not taken over since 1990 in Bangladesh. Secondly, it is found in the study that democracy in Bangladesh has been surviving on the system of CG but this study has not carried out any sort of investigation into whether or not the people support the CG system. Thirdly, the system of CG, meanwhile, has been abolished but this paper has not focussed on future of the country's democracy when the next general election will come up in early 2014. Future studies can cover these areas and, finally, look for a new system like CG that somehow represents people.

\section{References}

Ahmed, N. (2001). Parliamentary committees and parliamentary government in Bangladesh. Contemporary South Asia, 10(1), 11-36.

Ahmed, N. (2003). From monopoly to competition: Party politics in the Bangladesh Parliament (1973-2001). Pacific Affairs, 76(1), 55-77.

Akram, S. \& Das, S. K. (2006). Bangladesh Election Commission: A diagnostic study. Transparency International Bangladesh. Retrieved December 10, 2008, from http://www.tibangladesh.org/research/ES_ElectionCommission.pdf

Akram, S. \& Das, S. K. (2007). Tracking the election process: An analysis of the violations of electoral code of conduct by the candidates of the Postponed ninth parliamentary election. Transparency International Bangladesh. Retrieved December 10, 2008, from http://www.tibangladesh.org/research/ES_ElectionTracking3.pdf

Ali, R. (2006). Bangladesh in 2005: Standing at a Crossroads. Asian Survey, 46(1), 107-113.

Apter, D. (1965). The politics of modernization. Chicago: University of Chicago Press.

Azad, A. K. (2004). How party financing system works in advanced democracy: A case of New Zealand. Unpublished M.A. research paper, University of Auckland, Auckland.

Aziz's appointment as CEC was illegal for holding dual offices. (2007, December 13). The Daily Star, The Law \& Our Rights page. Retrieved February 12, 2009 from http://www.thedailystar.net/law/2007/12/03/week.htm

Barany, Z. (2004). Europe moves eastward: NATO's peaceful advance. Journal of Democracy, 15(1), 63-76.

Choudhury, N. K. (2006). A new arithmetic. The Daily Star (Dhaka): supplement on Election 2007, October 6, 2006. Retrieved December 27, 2007, from http://www.thedailystar.net/suppliments/2006/election2007/

Boix, C. \& Stokes, S. (2003). Endogenous democratization. World Politics, 55(4), 517-549.

Brownlee, J. (2009). Portents of pluralism: how hybrid regimes affect democratic transitions. American Journal of Political Science, 53(3), 515-532.

CSCW. (2006) Vanhanen's Index of Democracy. Retrieved February12, 2006, from http://www.prio.no/CSCW/Datasets/Governance/Vanhanens-index-of-democracy/

Cox, M., Ikenberry, J. \& Inoguchi, T. (2000). American democracy promotion - impulses, strategies, and impacts. Oxford: Oxford University Press.

Cui, Z. (1997). Privatization and the consolidation of democratic regimes: An analysis and an Alternative. Journal of International Affairs, 50(2), 675-692 
Doors shut free, fair polls. (2011). The Daily Star. Retrieved August 12, 2011 from http://www.thedailystar.net/newDesign/news-details.php?nid=192306

Ershad's takeover also illegal. (2010). The Daily Star. Retrieved November 7, 2010 from http://www.thedailystar.net/story.php?nid=89874

Freedom House. (2008). Freedom in the World. Retrieved November 21, 2008, from http://www.freedomhouse.org/report-types/freedom-world

Gazibo, M. (2005). Foreign aid and democratisation: Benin and Niger compared. African Studies Review, 48(3), 67-87.

Geddes, B. (1999). What do we know about democratization after twenty years? Annual Review of Political Science, 2(1), 115-144.

Haggard, L. \& Kaufman, T. (1995). The political economy of democratic transitions. Princeton: Princeton University Press.

Harris, R. L. (2004). Democratisation of the state: A global perspective and South African case study. International Journal of Public Administration, 27(13-14), 1061-1100.

HC declares void electoral roll. (2007). The Daily Star, The Law \& Our Rights page. Retrieved February 21, 2009, from http://www.thedailystar.net/law/2007/03/05/week.htm

Hossain, A. (2000). Anatomy of hartal politics in Bangladesh. Asian Survey, 40(3), 508-529.

Hossain, D. (2004). Bangladesh: Impact of globalisation and governance. South Asian Journal, 6 (OctoberDecember 2004). Retrieved 17 December 17, 2008, from http://southasianmedia.net/Magazine/Journal/6_bang_impact.htm

Huq, A. F. (1994). Bangladesher Rajniti: Sanghat O Paribartan1971-1991 (Bangladesh politics: Conflict and change1971-1991). Rajshahi (Bangladesh): Rajshahi University Text Book Board.

Huntington, S. P. (1991). Third wave: Democratization in the late 20th century. Norman: University of Oklahoma Press.

Huntington, S. P. (1968). Political order in changing societies. New Haven: Yale University Press

Iajuddin quits as chief adviser. (2007). The Daily Star, front page. Retrieved 5 April, 2010 from http://www.thedailystar.net/2007/01/12/d7011201011.htm

Immigration and Refugee Board of Canada. (1996). Bangladesh: political developments and political violence. Retrieved December 10, 2008, from http://www2.irbcisr.gc.ca/en/research/ndp/ref/index_e.htm?docid=118\&cid=30

Inglehart, R. \& Christian, W. (2005). Modernization, cultural change and democracy: The human development sequence. New York and Cambridge: Cambridge University Press.

Jahan, R. (2004). Bangladesh in 2003. Asian Survey, 44(1), 56-61.

Jahan, R. (2003). Bangladesh in 2002: Imperilled Democracy. Asian Survey, 43(1), 222-229.

Khan, M. M. \& Husain, S. A. (1996). Process of democratization in Bangladesh. Contemporary South Asia, 5(3), 319-334.

Kochanek, S. A. (1997). Bangladesh in 1996: The 25th year of independence. Asian Survey, 37(2), 136-142.

Kochanek, S. A. (2000). Governance, patronage politics, and democratic transition in Bangladesh. Asian Survey, 40, 530-550.

Kopstein, J. S. \& Reilly, D. A. (2000). Geographic diffusion and the transformation of the post-communist world. World Politics, 53(1), 1-37.

Lee, J. (2002). Primary causes of Asian democratization: Dispelling conventional myths. Asian Survey, 42(6), 821-837.

Lerner, D. (1958). The passing of traditional society. New York: Free Press of Glencoe.

Lipset, S. M. (1959). Some social prerequisites for democracy: economic development and political legitimacy. American Political Science Review, 53(1), 69-105.

Maniruzzaman, T. (1992). The fall of the military dictator: 1991 elections and the prospect of civilian rule in Bangladesh. Pacific Affairs, 65(2), 203-224.

Majumder, S. (2012). Democracy in Bangladesh. Retrieved July 7, 2012 from http://www.democracyasia.org/qa/bangladesh/Shantanu\%20Majumder.pdf

Moniruzzaman, M. (2009). Parliamentary democracy in Bangladesh: An evaluation of the parliament during 1991-2006. Commonwealth and Comparative Politics, 47(1), 100-126.

Mansfield, E. D. \& Pevehouse, J. C. (2006). Democratisation and international organisations. International Organisation, 60(1), 137-167. 
Moore, B. (1966). The social origins of dictatorship and democracy: Lord and peasant in the making of the modern world. Boston MA: Beacon Press.

Mujib: Death of the Founder. (1975). Time. Retrieved 1 December 2008 from http://www.time.com/time/magazine/article/0,9171,913420,00.html

National Democratic Institute. (2006r). Bangladesh 2007 elections. NDI Election Watch, 1. Retrieved February 28, 2009 from http://www.ndi.org/files/2103_bd_watch1_122106.pdf

Nelson, S. \& Wallace, G. (2005). Conditional credibility: explaining the impact of the IMF on democratization. Conference papers presented at annual meeting of American Political Science Association; Washington DC, p1-39. Retrieved May 20, 2009, from Academic Search Premier

O'Donnell, G. (1973). Modernization and bureaucratic-authoritarianism: Studies in South American politics Berkeley: Institute of International Studies, University of California,

O'Loughlin, J., Ward, M. D., Lofdahl, C. L., Cohen, J. S., Brown, D. S., Reilly, D., Gleditsch, K. S. \& Shin, M. (1998). The diffusion of democracy, 1946-1994. Annals of the Association of American Geographers, 88(4), 545-574.

Osman, F. A. (2010). Bangladesh Politics: Confrontation, Monopoly and Crisis in Governance. Asian Journal of Political Science, 18(3), 310-333.

Polity (2009). Polity IV dataset. Retrieved March 2, 2007 from http://www.systemicpeace.org/inscr/inscr.htm

Poll results. (2008). The Daily Star. Retrieved April 4, 2009 from http://www.thedailystar.net/newDesign/election/index.php

Przeworski, A. \& Limongi, F. (1997). Modernization: Theories and facts, World Politics, 49(3), 155-184.

Rahman, A. (2001). Democratization in South Asia: Bangladesh perspective. Bangladesh Political Science Review, 1(1), 1-22.

Rashiduzzaman, M. (2001). Bangladesh in 2000. Asian Survey, 41(1), 122-130.

Rose, R. \& Shin, D. C. (2001). Democratization backwards: The problem of Third-Wave democracies. British Journal of Political Science, 31(2), 331-354.

Rostow, W. W. (1960). The stages of economic growth. Cambridge: Cambridge University Press.

Rowen, H. S. (1995). The tide underneath the Third Wave. Journal of Democracy, 6(1), 52-64.

Rupnik, J. (2000). Eastern Europe: The international context. Journal of Democracy, 11(2), 115-129.

Schumpeter, J. (1947). Capitalism, socialism and democracy (2nd ed). London and New York: Routledge (Retrieved July 6, 2012 from http://sergioberumen.files.wordpress.com/2010/08/schumpeterjoseph-a-capitalism-socialism-and-democracy.pdf)

South Sea Republic. (2010). Non-party caretaker government. Retrieved December 23, 2010 from http://www.southsearepublic.org/article/589/read/bangladeshs_nonparty_caretaker_governmentT ransparency

SC sets aside caretaker system. (2011). bdnews24.com. Retrieved August 13, 2011 from http://www.bdnews24.com/details.php?id=195305\&cid=2

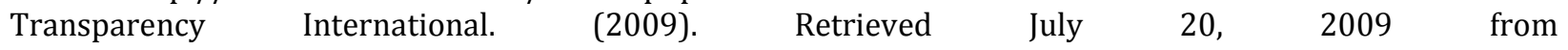
http://www.transparency.org/policy_research/surveys_indices/cpi

UNDP. (2005). Beyond Hartals: Towards democratic dialogue in Bangladesh, Retrieved August 12, 2009 from http://www.undp.org.bd/publications/Beyond\%20Hartals.pdf

UN Stat. (n.d.). Basic data selection. Retrieved April 20, 2009, from http://unstats.un.org/unsd/snaama/selectionbasicFast.asp

UN Stat Conversions and Formulas. (2007). Retrieved February 5, 2007, from http://unstats.un.org/unsd/snaama/formulas.asp

Vanhanen, T. (2004). Struggle for democracy in Sub-Saharan Africa. Acta Politica, 39(3), 207-247.

Vanhanen, T. (2003). Democratization: A comparative analysis of 170 countries. London and New York: Rutledge.

Venter, D. (2003). Democracy and multiparty politics in Africa: Recent elections in Zambia, Zimbabwe, and Lesotho. Eastern Africa Social Science Research Review, 19(3), 1-40.

Wejnert, B. (2005). Diffusion, development, and democracy, 1800-1999. American Sociological Review, 70(1), 53-81.

Wilkinson, S. I. (2000). Democratic consolidation and failure: Lessons from Bangladesh and Pakistan. Democratization, 7(3), 203-226.

Wollheim, R. (1958). Democracy. Journal of the History of Ideas, 19(2), 225-242. 